\title{
PERIBAHASA BAHASA REJANG
}

\author{
Indah Pujiastuti \\ Prodi Pendidikan Bahasa dan Sastra Indonesia, FKIP \\ Universitas Maritim Raja Ali Haji (UMRAH) \\ Pos-el: indah.puji@umrah.ac.id
}

\begin{abstract}
A bstrak
Peribahasa merupakan ungkapan tradisional yang menjadi bagian dari sastra lisan. Di Masyarakat Rejang, peribahasa tersebut dimunculkan secara lisan di acara adat seperti pernikahan dan dimunculkan dalam peraturan adat Rejang. Penelitian ini bertujuan untuk mendeskripsikan peribahasa dari Msayarakat Rejang khususnya masyarakat Kabupaten Rejang Lebong. Peribahasa tersebut dideskripsikan dari aturan adat yang sudah direkam dalam bentuk tulis yaitu Kelpeak Ukum A dat (Hukum A dat Rejang). Penelitian ini juga untuk mengetahui fungsi dari peribahasa tersebut. Penelitian ini menggunakan pendekatan kualitatif dengan metode deskriptif yang bersumber dari hukum adat Rejang yaitu Kel peak Ukum A dat N gen Riyan Ca'o Kutei Jang yang memuat tentang tata cara bermasyarakat, hak dan kewajiban masyarakat, adatpernikahan, warisan, tarian, kepemimpinan, busana, bahasa, dan tulisan. Penelitian ini menitikberatkan pada analisis dokumen. Hasil yang didapatkan, bahwa 29 peribahasa yang ditemukan dalam hukumadat tersebut membahas tentang tatanan hidup masyarakat Rejang. Peribahasa tersebut berfungsi sebagai nasihat, larangan, teguran, pengajaran, gambaran tatanan sosial bermasyarakat.
\end{abstract}

Kata Kunci: Peribahasa, Suku Rejang, HukumA dat

\begin{abstract}
Proverbs aretraditional expressions that are part of oral literature. In Rejang Community, the proverb was raised orally in traditional events such as weddings and raised in the R ejang customary law. This study aims to describe the proverbs of M sayarakat R ejang, especially the people of R ejang Lebong R egency. The proverb is described from customary rules that have been recorded in written form of Kel peak U kum A dat (Custom Rejang Law). This research is also to know the function of theproverb. This research used qual itativeapproach with descriptive method that comed from customary law of Rejang namely K el peak U kum A dat $\mathrm{N}$ gen Riyan $\mathrm{Ca}^{\prime} \mathrm{O}$ Kutei Jang which contains about social, community and rights, customs, and writing. This study focused on content analysis. The results obtained, that the 29 proverbs found in the customary law is about the life order of the Rejang community. These proverbs serveas advice, prohibitions, admonitions, teachings, images of the social fabric of society.
\end{abstract}

Keywords: Proverb, Rejang Community, Customary Law

\section{PEN DAHULUAN}

Di Provinsi Bengkulu, terdapat suku Rejang yang menempati daerah Kabupaten Rejang Lebong, Kabupaten Kepahiang, Kabupaten Bengkulu Tengah, Kabupaten Lebong, Kabupaten Bengkulu Utara. Daerah yang disebut Bumei $P$ at Petulai,yaitu daerah yang didiami oleh 4 keturunan pemimpin (kutei). Suku Rejang dikenal dengan tulisan dan bahasanya yang unik yang telah dikenali di kalangan akademik. Suku Rejang memiliki unsur-unsur kebudaya- an yang mempunyai nilai budaya yang tinggi dan luhur. Perwujudan unsur kebudayaan daerah itu antara lain berupa bahasa dan aksara, organisasi sosial, sistem upacara adat, permainan rakyat, makanan khas, peralatan dan kesenian tradisional, kerajinan rakyat serta semua bentuk peninggalan sejarah.

Unsur kebudayaan itu pun termasuk bagian dari folklor lisan (verbal folklore). Dalam folklor lisan terdapat yang namanya ungkapan tradisional yaitu kalimat pendek yang disari- 
kan dari pengal aman yang panjang. Foklor lisan itu disebut peribahasa. Peribahasa biasanya mengandung kebenaran dan kebijaksanaan.

Foklor lisan tersebut satu di antaranya tertuang dalam Kelpeak Ukum A dat Rejang (hukum adat Rejang) yang telah dihimpun dan dibukukan. Hasil penelitian peneliti dalam makalah yang berjudul "Membangun Karakter Melalui Adat Istiadat 'Kelpeak Ukum Adat Ngen Riyan Ca'o Kutei Jang' Kabupaten Rejang Lebong" (Pujiastuti, 2017:475) menunjukkan bahwa aturan-aturan adat Rejang tidak hanya disampaikan dengan pernyataan langsung tetapi disampaikan dengan makna kiasan. Sehingga peneliti mencoba menemukan dan memetakan makna kiasan tersebut sebagai peribahasa-peribahasa yang muncul di dalam hukum adat tersebut. $\mathrm{Hal}$ ini juga diperkuat oleh penjelasan Hutomo (1991:67) bahwa secara tersirat di peribahasa terkandung tentang undang-undang adat atau peraturan adat.

Sudah dikenal dalam adat masyarakat timur bahwa ketika menyampaikan sesuatu dilakukan secara tidak langsung, dengan kiasan ataupun gaya bahasa. Banyak pertimbangan yang menyebabkan penyampaian maksud secara tidak langsung, di antaranya menghindari ketersinggungan seseorang. Dengan adanya ujaran tertentu metafora ini sering digunakan untuk pengaburan arti bahasa. Oleh sebab itu dalam peribahasa, tersirat unsur sistem budaya masyarakat yang berkaitan dengan nilainilai, pandangan hidup, norma, petunjuk dan aturan yang menjadi acuan bagi anggota masyarakat.

Sayangnya peribahasa-peribahasa itu kurang populer pada kalangan muda. Karena selain tidak mengenalnya dan tidak ada keinginan untuk mempelajarinya, peribahasaperibahasa ini hanya ditemukan sesekali misalnya dalam musyawarah perangkat desa, acara pernikahan. Hal ini juga dibuktikan dalam artikel "Serambeak: Sastra Lisan Suku Rejang yang Nyaris Punah" (Lebong, 2007) bahwa dijelaskan kalangan orang tua yang memahami kebudayaan Rejang sudah berkurang dan bukti tertulis banyak ditinggalkan.

Padahal peribahasa-peribahasa tersebut memiliki nilai-nilai yang relevan dengan kehidupan saat ini. Artinya nilai-nilai tersebut masih dapat diterapkan, bahkan masih sangat diperlukan untuk membawa masyarakat kembali pada nilai-nilai luhurnya. $\mathrm{Hal}$ ini termuat dalam hasil penelitian Pulungan (2013) yang menyatakan, “Dari segi Etnolinguistiknya, peribahasa Bahasa Indonesia juga sarat dengan nilai-nilai moral dan budaya yang mencerminkan kondisi masyarakat Indonesia". Kemudian penelitian Sunarni tentang peribahasa (2017:405) bahwa “... Penggunaan peribahasa dalam komunikasi di masyarakat sangat efektif sebagai pewarisan budaya. Penelitian ini bermanfaat untuk dijadikan model aplikasi pewarisan budaya melalui peribahasa sebagai dasar pandangan hidup masyarakat Indonersia di era global." Dapat disimpulkan bahwa peribahasa terutama yang berasal dari kebudayaan daerah adalah sumber dan berperan penting dalam pertumbuhan dan memperkaya nilai-nilai kebudayaan nasional.

Dengan mengetahui peribahasa yang ada di daerah, kita dapat mengetahui gambaran mengenai berbagai aspek tatanan hidup masyarakat tertentu dan dapat pula membina pergaulan serta pengertian bersama sebagai suatu bangsa yang memiliki aneka ragam kebudayaan. Wujud dan unsur kebudayaan daerah tersebut perlu digali, diteliti, dibina, dan dilestarikan secara bersama yang didukung oleh kualitas manusia, sarana, dan dana yang digunakan untuk membendung nilai-nilai baru yang muncul karena arus modernisasi dan globalisasi.

Berdasarkan penjelasan di atas, penelitian ini bertujuan untuk mengetahui peribahasa yang terdapat di dalam hukum adat yang terangkum dalam “Kelpeak Ukum A dat N gen Riyan Ca'o Kutei Jang Kabupaten Rejang Lebong". Di dalam Dari peribahasa tersebut juga akan dilihat fungsi peribahasa Rejang. 


\section{TEORI DAN METODE}

Sastra lisan merupakan bagian dari kajian sastra yang disebut LiteratureT ransmitted 0 rally atau dalam bahasa Inggris oral literature atau dalam bahasa Belanda orale letterkunde atau yang dikenal dengan istilah folklore. Sastra lisan adalah "kesusastraan yang mencakup ekspresi kesusastraan warga suatu kebudayaan yang disebarkan dan diturun-temurunkan sastra lisan dari mulut ke mulut (Astika dan Yasa, 2014:2)." Jadi pada dasarnya sastra lisan merupakan warisan budaya masa lampau yang diturunkan dalam masyarakat dengan nilai-nilai lokal budaya yang penyebarannya dari mulut ke mulut kemudian karena perkembangan zaman dan gencarnya pelestarian budaya beberapa sastra lisan dibukukan sebagai rekaman dari sastra lisan itu sendiri.

Pada masyarakat, sastra lisan mempunyai fungsi sendiri. Di antaranya ada tujuh fungsi sastra lisan, yaitu: 1) sebagai sistem pemertahanan diri terhadap keadaan yang ada di kehidupan (proyeksi); 2) sebagai pengesahan dan pembenaran suatu kebudayaan; 3) sebagai alat pemaksa berlakunya norma sosial; 4) sebagai alat dalam pendidikan anak; 5) memberikan pedoman dalam menjalakan kehidupan; 6) memberikan jalan agar dapat mencela orang lain dalam masyarakat; 7) sebagai alat untuk memprotes ketidakadilan dalam masyarakat; dan 8) sebagai sarana hiburan (Hutomo, 1991: 69-74). Sastra lisan juga berfngsi sebagai alat untuk menyampaikan pemikiran, pencerminan diri, serta ekspresi rasa keindahan (Sugono, 2011:113). Dapat disimpulkan sastra lisan dijadikan sebagai buah pikiran untuk menunjukkan ekspresi terhadap kehidupan yang bisa dijadikan sebagai pedoman kehidupan karena memiliki norma-norma yang berlaku di suatu masyarakat.

Bagian dari sastra lisan itu mencakup ungkapan tradisional, nyanyian rakyat, bahasa rakyat, teka teki, dan cerita rakyat (H utomo, 1991:8). Peribahasa adalah bagian dari ungkapan tradisional. Menurut Za'ba (1965:165 dalam
Hassan dan Jaafar, 2016:96) peribahasa ialah "Segala susunan cakap yang pendek yang telah melekat di mulut orang ramai sejak beberapa lama oleh sebab sedap dan bijak perkataannya, luas dan benar tujuannya- dipakai akan dia jadi sebutan-sebutan oleh orang sebagai bandingan, teladan, dan pengajaran. Pendapat ini sejalan dengan pengertian di KBBI (2015) bahwa peribahasa adalah kalimat atau kata yang mengumpakan dan mengiaskan maksud atau tujuan tertentu isinya bisa berisi nasihat, aturan tingkah laku, larangan.

Penelitian Yulyasa, dkk. (2017), merangkum bahwa bagian dari peribahasa adalah pepatah, perumpaan, bidal, dan pameo (ungkapan). Menurut Kamus Besar Bahasa Indonesia, pepatah adalah peribahasa yang mengandung nasihat atau ajaran dari orang tuatua; perumpamaan adalah peribahasa yang berupa perbandingan; bidal adalah peribahasa yang mengandung nasihat, peringatan, sindiran; dan ungkapan adalah kelompok kata atau gabungan yang menyatakan makna khusus yang makna unsurnya seringkali kabur. Dari penjelasan tersebut ditegaskan bahwa peribahasa dimaksudkan untuk menyampaikan nasihat, Iarangan, teguran, bahkan sindiran yang maksud sebenarnya untuk memberikan arahan terhadap tingkah laku. Hal ini dipertegas juga dengan pendapat Indirawati (1998):

"Penggunaan peribahasa ini sebenarnya mempunyai fungsi yang sangat menarik. Peribahasa digunakan dengan tujuan untuk menyampaikan maksud yang tertentu dengan cara yang cukup halus atau berlapik. Peribahasa juga berfungsi sebagai peringatan, nasihat dan kritikan untuk tujuan kebaikan kepada seseorang. Penggunaan peribahasa berupaya membawa mesej nasihat tanpa menyinggung hati seseorang. Selain itu, penggunaannya mempunyai objektif yang tersendiri, iaitu supaya orang yang mendengar atau membacanya tidak mudah rasa tersinggung dalam sesebuah komunikasi (Hassan dan Jaafar, 2016:96)."

Fungsi peribahasa tidak jauh berbeda dengan fungsi sastra lisan secara keseluruhan. 
Dirangkum dari buku Hutomo (1991:67), peribahasa berfungsi sebagai 1 ) alat pedagogis (mendidik); 2) alat pemaksa berlakunya normanorma sosial; 3) sebagai alat pengendalian sosial; 4) menambah kewibawaan seseorang.

Peribahasa yang akan diteliti adalah peribahasa Bahasa Rejang. Yaitu peribahasa yang digunakan oleh suku Rejang yang sudah termuat dalam himpunan hukum adat "Kelpeak Ukum A dat Ngen Riyan .

Suku Rejang adalah satu di antara suku tertua di Sumatera. Suku Rejang dikenal dengan bahasa Jang atau disebut bahasa Rejang dan aksara Ka-ga-nga yang mendiami daerah di Bengkulu. Daerah yang didiami masyarakat Rejang dikenal dengan nama "Bumei Pat Petulai" (bumi empat petulai), yaitu daerah yang dipimpin oleh 4 kelompok yang disebut Biku. Kelompok tersebut adalah

a. Biku Sepanjang Jiwo, memimpin kelompoknya yang dinamakan dengan P etulai Tubeui atau Tubai.

b. Biku Bermano, memimpin kelompok yang dinamakan dengan sebutan Petulai Bermani atau Bemani.

c. Biku Bembo, memimpin kelompok yang dinamakan dengan sebutan Petulai Jekalang atau Jurukalang.

d. Biku Bejenggo, memmimpin kelompok yang dinamakan dirinya dengan sebutan Bang Petulai Sel upueatau Selupu. (Abdulah Sidik, 1986: 32 dalam Herlambang, 2004:7).

Suku Rejang memiliki berbagai macam sastra lisan seperti $\mathrm{N}$ andei (dongeng), Geritan (cerita legenda berbau mistis), Berdai (bercerita), Pantun, Rejung (Syair), Sambei (nyanyian tradisional), Serambeak (peribahasa). Peribahasa (serambeak) dimunculkan di dalam hukum adat sebagai pedoman dalam mengatur tingkah laku serta sebagai identitas masyarakat Rejang.

Jika dilihat dari tujuannya, maka penelitian ini termasuk penelitian kualitatif yang menggunakan metode deskriptif. Moleong (2007:3) berpendapat bahwa "Penelitian kualitatif sebagai prosedur penelitian yang menghasilkan data deskriptif berupa kata-kata tertulis atau lisan dari orang-orang dan perilaku yang dapat diamati." Data deskriptif yang akan dihasilkan bersumber dari Kelpeak Ukum Adat $\mathrm{N}$ gen Riyan Ca-o Kutei Jang Kabupaten Rejang Lebong. Himpunan Hukum Adat Rejang tersebut disusun pada tahun 2007 oleh Badan Musyawarat A dat Kabupaten Rejang Lebong yang terdiri atas 96 hal aman. Isinya terdiri dari 52 pokok aturan adat, 17 bagian pohon adat (Pun Adat), pembahasan mengenai bahasa, tulisan, hak raja (hak pemimpin), aturan mengenai pemimpin desa, hulubalang, aturan mengenai penyelesaian masalah, harta warisan, pernikahan, adat bujang gadis, utang piutang, tarian, dan busana adat.

Sedangkan metode penelitian yang digunakan untuk mengumpulkan dan menentukan fungsi dari peribahasa yang termuat dalam Kelpeak Ukum Adat Ngen Riyan Ca-o Kutei Jang Kabupaten Rejang Lebong adalah metode deskriptif. Metode ini digunakan untuk menggambarkan secara sistematis, faktual, dan akurat tentang fakta-fakta yang ada, yang dalam penelitian ini berupa peribahasa yang terdapat dalam buku hukum adat Rejang. Untuk mengumpulkan data perlu instrumen penelitian. Karena penelitian ini adalah penelitian

Karena pengumpulan data berupa dokumentasi dari naskah, teknik analisis data sesuai dengan pembahasan Creswell (2014:276) sebagai berikut:

a. Mengolah dan mempersiapkan data untuk dianalisis. Langkah ini untuk memilah data di dalam Himpunan Hukum Adat Rejang. Memilih data yang merupakan hukum adat yang berbentuk peribahasa.

b. Membaca keseluruhan data. Menuliskan gagasan atau cacatan khusus yang ditemukan setelah memilih data.

c. Menganalisis lebih detail dengan mengcoding data. Langkah ini merupakan proses 
pengolahan data dengan memaknai sesuai teori yang ada.

d. Menginterpretasi deskripsi-deskripsi dari data yang sudah dianalisis kemudian disimpulkan.

\section{HASIL DAN PEMBAHASAN}

\section{a. Peribahasa dalam Kelpeak Ukum Adat Rejang}

Peribahasa dalam bahasa Rejang disebut dengan "serameak padeak/ serameak kecek", dari hasil pengamatan pada kumpulan hukum adat Rejang, peneliti menemukan bahwa pokok aturan adat Rejang selain disampaikan secara denotasi juga disampaikan dengan bahasa kiasan. Bahasa kiasan ini terwujud dalam bentuk peribahasa. Peribahasa-peribahasa tersebut disajikan sebagai berikut:

1. Mueak kakane ade, beripit kekeane coa (hal. 4)

(gampang bagi mereka yang punya, sulit bagi yang tidak punya)

Ungkapan di atas menunjukkan sikap dalam tolong menolong dalam memberikan bantuan kepada yang membutuhkan tanpa melihat besar atau tidak jumlah pemberiannya, tetapi keikhlasannya.

2. Bebanea inde benuo (hal. 5)

(Pokok batang rotan manau)

Rotan manau adalah tumbuhan rotan yang apabila akan diambil rotannya maka harus mencari pangkal pohon agar bisa ditebang. Dari peribahasa tersebut bermakna dalam menyelesaikan masalah harus dicari dulu awal mula permasalahannya.

3. Be tutun inde jalei (hal. 5)

(Tali jala)

Bermakna bahwa permasalahan itu ibarat jala, yang harus dibongkar dengan me lepaskan rajut jala dan menjadikannya tali sehingga bisa diselesaikan.
4. Ade lot ade ei (hal. 6)

(Ada hilir ada hulu sungai)

Hal ini jika dikaitkan dengan wilayah pemukiman Rejang:

(a) Bahwa masyarakat Rejang daerah pemukimannya biasanya di pinggiran sungai, ini salah satunya dibuktikan dengan pemukiman asli suku daerah Rejang Lebong, yaitu daerah-daerah yang berada di pinggiran sungai Tabarenah, yaitu daerah Dusun Curup, Simpang Empat, Talang Kering, Tapus, Perbo, Tanjung Beringin.

(b) Sungai merupakan sarana penghubung bagi masyarakat Rejang untuk mengadakan hubungan silahturahmi serta menyampaikan berita atau pesan, juga sebagai sarana perekonomian di masa lalu. Pada masa ini sungai hanya digunakan untuk keperluan sehari-hari seperti mandi, mencuci, dan untuk sumber nafkah (dengan mengambil batu di sungai).

(c) Masyarakat di bagian hulu sungai dengan masyarakat di bagian hilir sungai, merupakan satu kesatuan masyarakat. Sehingga baik masyarakat bagian hulu maupun hilir saling bertenggang rasa.

Pada dasarnya peribahasa ini, memberikan pelajaran bahawa Masyarakat Rejang harus selalu berdampingan dan gotong royong di mana pun dia berada.

5. Pendak dik sudo, panjang gik igei (hal. 7) (Pendek sudahkan, panjang habiskan)

Peribahasa ini bermakna, ketika masalah sudah diselesaikan secara adat maka masalah tersebut dianggap sudah selesai dan diharapkan untuk belajar ikhlas dan berlapang dada.

6. Pecoak bekaping (hal. 9) (pecah dipasang kaping) 
P ecoak berarti retak atau pecah untuk berbagai benda yang memiliki gagang seperti parang, pisau, sedangkan bekaping memiliki kaping yang menempel, kaping itu berbentuk tali atau rotan, atau alat yang dapat menyatukan gagang yang pecah atau rusak pada parang, sehingga dapat digunakan lagi

Maksud dari pecoak bekaping ini adalah, jika kita (siapa pun itu) mengetahuinya adanya upaya untuk memecah belah atau pun terjadi hal-hal yang memecah belah kehidupan masyarakat Rejang, maka diupayakan untuk merapatkan mereka kembali/ memperbaiki masalah-masalah yang terjadi. Masyarakat Rejang memahami adanya budaya tanggung jawab dan penyelesaian masalah dengan cara musyawarah, menjadikan yang retak utuh kembali.

7. Sumbing, betitip (hal. 10)

(sumpil/ sumbing ditempa,maksudnya alat rumah tangga, seperti kuali, periuk, jika dipakai terlalu lama akan sumpil atau ada kerusakan sedikit, maka kerusakan itu dapat kita tempa/ betitip kembali agar bagus kembali).

Sama seperti pecoak bekaping, makna dalam perumpamaan ini bahwa jika ada masalah maka perlu diperbaiki, tetapi masalah ini bukan yang terjadi di masyarakat tetapi dalam berkeluarga, jadi jika keadaaan suatu keluarga tidak harmonis, maka penempanya adalah orang tua, orang tua yang wajib mengakurkan baik secara kekeluargaan biasa maupun upacara adat.

8. Betimbang samo benek, bekilo samo kelengan, bekulak samo penoak, bageak samei kedeu (hal. 11-12)

(Menimbang sama beratnya, mengilo sama ringannya, mengulak sama penuhya, membagi sama rata)

Ungkapan di atas memiliki satu makna yang sama tentang berdagang, berjualan, dan dalam kehidupan. Ketika melaksanakan kegiatan berdagang maka diharapkan penjual jujur, ketika memiliki masalah dalam rumah tangga maka harus diselesaikan secara objektif tanpa memihak. Segala sesuatu dilihat dari dua sisi, positif dan negatif, manfaat dan mudaratnya. Kejujuran sangat dijunjung tinggi dalam masyarakat, maka berlaku adil dan jujur itu yang diharapkan dalam kehidupan rakyat Rejang.

9. Titik jibeak maghep anak, tuwei ati teu si bapak (hal. 14)

(Kecil jangan dianggap anak, tua tidak tau jika bapak)

Maksudnya bahwa yang kecil jangan dianggap anak-anak, yang tua belum tentu dewasa. Bahwa usia tidak menjadi patokan untuk memeroleh ilmu dari seseorang. IImu dapat didapatkan dari orang-orang yang memiliki pengalaman dan wawasan yang cukup. Contoh seorang pemuka adat di Rejang tidak terbatas orang-orang tua yang berusia di atas 60 tahun. A kan tetapi orang-orang yang berusia 30 tahun, 40 tahun sudah bisa dianggap sebagai pemuka adat apabila memahami apa-apa saja aturan adat yang berlaku di masyarakat Rejang.

10. Tuwei badou (hal. 14)

(Tuba akar yang tidak membunuh) Yang menjelaskan bahwa manusia yang tidak tahu apa-apa (tidak memiliki kemampuan apa-apa) tidak ada gunanya dalam masyarakat. Ungkapan ini memiliki keterkaitan dengan peribahasa "Titik jibeak maghep anak, tuwei ati teu si bapak" karena penjelasan tentang manusia dewasa bukan dilihat dari umurnya, sehingga orang yang dianggap sudah berumur tetapi tidak memiliki pengetahuan dan kedewasaan disebut dengan tuwei badou.

11. Cong laboak may biyoa (hal. 14)

(Mencincang air) 
Yang maksudnya bahwa jika di dalam kehidupan di tengah masyarakat, bila terjadi perselisihan antara mereka mereka yang masih ada hubungan darah dan daging, maka tidak boleh diperpanjang dan bahkan pihak luar tidak diperkenankan untuk membantu penyelesaiannya, biarkanlah mereka menyelesaikan sendiri urusannya.

12. Bepatet bekenek, bejenjang tu'un (hal. 16) (Berjenjang naik, berjenjang turun)

Peribahasa ini berhubungan dengan tempat untuk naik dan turun rumah panggung. Rumah panggung ditapaki anak tangganya satu persatu untuk naik, untuk turun meluncur memegang kayu sebatang, dalam kehidupan masyarakat Rejang di masa lalu, rumah adat Rejang biasanya tinggi dan bertangga, untuk naik ke atas kita menggunakan tangga, sedangkan sarana untuk turun disipakan satu batang kayu, sehingga untuk turun dari rumah kita meluncur memegang batang kayu tersebut.)

Mempunyai pengertian bahwa dalam menyelesaikan suatu pekerjaan haruslah mengikuti aturan yang telah digariskan seperti menapaki anak tangga, jika terdapat maslaah harus segera diselesaikan dikiaskan dengan turun menggunakan kayu sebatang.

13. Tangen menetok baeu mbusung (hal. 20) (tangan memotong bahu membusung) $\mathrm{Hal}$ ini berkenaan dengan tanggung jawab kita akan suatu perbuatan, apabila kita melakukan sesuatu perbuatan maka segala akibat atau segala resiko atas perbuatan kita tersebut, maka kita yang harus bertanggung baik buruknya keadaan tersebut.

14. Ayak miling tenlen biyoa inoa (hal. 21)

(Sebelum berbicara telan liur dulu)

Sebagaimana orang bijak mengatakan bahwa mulutmu adalah harimaumu. Ada juga yang mengatakan bahwa kata-kata yang telah diucapkan tidak mungkin kita tarik kembali. Maka sebelum berbicara maka dipikirkan dulu terlebih dahulu, sehingga apa yang kita bicarakan tidak menyakiti orang lain, dan dapat dibuktikan serta dipertanggungjawabkan.

15. A yak bekenea, kabo tukuk (hal. 21) (Sebelum bertindak, pegang tengkuk) Artinya bila kita bertindak maka kita diminta untuk meraba tengkuk. Tujuan dari kata-kata memegang tengkuk adalah memberikan kesempatan kepada otak untuk berpikir. A pabilakita melakukan hal tersebut, maka berkemungkinan kecil tindakan kita tersebu mengarah kepada tindakan yang menjurus ke arah negatif. Artinya bahwa sebelum melakukan sesuatu pertimbangkan baik buruknya telebih dahulu.

16. Jibeak mbin sifet lalang bidin dalen (hal. 22)

(Jangan ambil sifat ilalang di jalan)

Kita mengetahui bahwa ilalang adalah sejenis rumput yang daunnya seperti padi dan tidak mempunyai pohon/ batang. Ilalang ini tumbuh di tanah yang kurang subur. Bila ada ilalang di pinggir jalan, kita dapat melihat sifatnya, jika ada angin dari kanan maka dia akan rebah ke kiri begitu sebaliknya. Ilalanng tidak dapat berdiri secara mantap, karena tidak punya batang atau pohon.

Maknanya bahwa manusia tidak boleh plin plan atau tidak teguh, serta tidak memiliki pendirian. Jika diberi kepercayaan, dia mengkhianatinya, jika diminta untuk menyelesaikan persoalan maka dia tidak dapat memberi keputusan yang objektif.

17. Cuwuo-cuwuo samo laleu, denong-denong samo belek (hal. 23)

(Mampir sama pergi, memandang sama balik)

Ungkapan yang menyatakan hal yang dilarang. Dalam kehidupan ketika tinggal 
di lingkungan masyarakat, ketika rumah kita melewati rumah orang tua atau mertua (yang sudah menikah), diharapkan untuk didatangi untuk menjaga silahturahmi, bukan sekadar dilihat saja.

18. Adat Coa melkang keno panes, coa mobok nukai ujen (hal. 30)

(Tidak lekang karena panas, tidak lapuk karena hujan)

Yang bermakna bahwa adat memiliki peraturan yang berlaku secara umum untuk masyarakat Rejang yang berpedoman dari kitab suci AI Quran, sehingga berlaku sepanjang zaman untuk masyarakat.

19. Saleak cong udi bepapet ( hal. 30) (Salah mencincang kamu merapat) Maknanya, jika kita melakukan kesalahan, maka berusahalah untuk mengembalikan keadaan seperti semula, dengan cara mengakui kesalahan dan meminta maaf.

20. Adat aleak nukai janjei (hal. 31)

(Adat kalah dengan janji)

Ungkapan yang bermakna bahwa ketika ada seseorang yang melakukan perjanjian walaupun bertentangan dengan adat, harus ditepati. Untuk mengatasi hal-hal yang tidak diinginkan dan tindakan yang kurang baik, maka ada aturan yang menjelaskan bahwa "Janji Kalah dengan Hukum".

21. Coa penoak mindas ma'ep besi'ng mimbeak (hal. 33)

(tidak penuh ke atas asal berisi ke bawah) Dalam kehidupan masyarakat Rejang, jika tidak bisa melakukan hal-hal yang bukan kewajiban (sunah) maka selesaikan saja yang kewajiban. Hal ini pun berlaku dalam jamuan makan pada acara tertentu, jika seseorang tidak mampu mengadakan hajatan dan tidak bisa menyediakan makanan berupa serawo dan ayam (serawo lengkap) untuk semua orang yang hadir, maka cukup menyediakan serawo punjung satu piring, serawo bukan punjung satu piring, satu piring nasi, satu piring (gulai) ayam, satu mangkuk cuci tangan, dan satu gelas air minum (hal ini sudah ketentuan adat Rejang). Bahwa yang diinginkan dari perjamuan itu bukan hal-hal yang berbau riya' atau pamer tetapi lebih pada keikhlasan. Untuk memperjelas serawo adalah nasi ketan dalam piring yang bagian atasnya diberikan bunga yaitu kelapa yang telah diparut dan digongseng sera dicampur dengan gula merah. Sedangkan serawo punjung adalah nasi ketan yang dicetak dengan mangkuk atau sejenisnya, sehingga berbentuk piramid atau tumpeng dan pada bagian atasnya diberi bunga serawo.

22. Beneak M beak Temambeak, Lengan M beak Mapei (hal. 36)

(Yang berat jangan ditambah, yang ringan jangan diabaikan)

Ungkapan ini bermakna bahwa setiap pelanggaran adat harus diberikan sanksi sesuai dengan porsinya masing-masing, tidak ditambah, tidak juga dianggap enteng. Agar masyarakat yang melakukan pelanggaran dapat memperbaiki kesalahannya dan belajar dari kesalahan tersebut.

23. Neak ipe bumei nelat, diba lenget jenunjung (hal. 36)

(di mana bumi dipijak, disitu langit dijunjung)

Mengandung makna bahwa dimana kita berada, kita harus mengikuti, melaksanakan, dan menghargai serta mendahulukan adat istiadat masyarakat ditempat kita tinggal. Jadi jika kita seorang pendatang dalam suatu daerah dalam kehidupan sehari-hari, kita harus mendahulukan adat istiadat masyarakat di tempat kita tinggal, baru kemudian kita melaksanakan adat istiadat kita, yang kita bawa dari daerah asal kita. 
24. Tiung bergalo iman bergageak (hal. 36) (Beo iman bergagah)

Tiung adalah beo, sedangkan iman adalah burung sejenis beo. Beo bisa diajar berbicara tetapi tidak memahami apa yang dibicarakan. Dalam adat Rejang, masyarakat dilarang memiliki sifat seperti beo atau iman, karena beo seperti menyombongkan diri (bergagah) tanpa mengerti apa yang dketahui.

25. Rajo megang peteine, anak kutei megong kuceine (hal. 41)

(raja pegang petinya, masyarakat pegang kuncinya)

A rtinya, rakyat dan pemimpin saling melengkapi dalam kehidupan.

26. Semitak buk neak gelpung, gelpung coa tupeak buk coa putus (hal. 65)

(Menarik rambut di tepung, tepung tidak tumpah rambut tidak putus)

Yang bermakna bahwa rambut dianggap masalah yang terjadi dalam kehidupan (tepung). Permasalahan tersebut bagaimana caranya agar bisa selesai jika asegala permasalahan diharapakan dapat diselesaikan dengan cara musyawarah, agar dapat diterima semua pihak.

27. Mbeak mayeak kiyeu dipoa mengindai (hal. 66)

(jangan mencondongkan kayu di seberang mengarah kita).

Peribahasaini dikaji dari segi penyelesaian suatu persoalan. Setiap permasalahan terkadang menyangkut dengan persoalan diri secara individu, terkadang juga tidak. A kan tetapi, ketika masalah itu muncul maka yang harus diutamakan adalah pe nyelesaian masalah secara adil, tanpa memihak. Seandainya suatu permasalahan akan menimbulkan risiko untuk kita sebagai individu, kita harus menerima dan menjal ankannya.

28. M beak temgak saman ceak (hal. 66) (janganlah menegakkan benang basah)
Maknanya: sebagai seorang yang telah dipercayakan untuk menyelesaikan masalah (seperti hakim/ jenang/ ketua adat), maka jangan sekali-kali berupaya mencari dalil pembenaran terhadap suatu perbuatan yang salah tersebut. Orang salah tetap salah dan dihukum, orang benar harus dilindungi sesuai dengan ketentuan hukum yang berlaku.

29. Jibeak mbin pegong puwea cundung mai kawuk (hal. 66)

(Janganlah menganut sifat pohon puwar condong ke lembah)

Sama maknanya dengan makna dari mbeak mayeak kiyeu dipoa mengindai, jika seorang hakim memiliki suatu permasalahan melibatkan pihak keluarganya, maka hakim tidak boleh memihak, tetapi melihat siapa yang salah dan benar, dan harus bersikap adil.

\section{b. Fungsi dari Peribahasa Rejang}

Peribahasa (proverbs) merupakan salah satu bentuk gaya bahasa yang berupa ungkapan tradisional atau suatu kiasan bahasa yang berupa kalimat atau kelompok kata yang bersifat padat, ringkas, sederhana dan berisi tentang norma, nilai, nasihat, perbandingan, perumpamaan, prinsip dan aturan tingkah laku (Widyastuti, 2010).

Terdapat fungsi peribahasa dalam kehidupan masyarakat Rejang sehari-hari:

1. Peribahasa banyak digunakan dalam kehidupan keseharian orang pada masa dulu dan diturunkan dari generasi ke generasi, karena dianggap sebagai jalan yang paling mudah bagi mereka untuk memberi nasihat, teguran atau sindiran. Demikian sebaliknya, isinya mudah ditangkap oleh pihak yang dinasehati. Bila diselidiki isi dan jiwa yang terkandung didalamnya, maka banyak bahan yang dapat diambil dari sejarah, sosial dan makna kehidupan mereka pada masa itu. Manusia dapat berpedoman pada nilai-nilai yang diwaris- 
kan oleh generasi sebelumnya (Baried, dkk.,1985:83), menyelesaikan permasalahan dengan nasihat-nasihat yang dimunculkan dalam bentuk peribahasa Seperti contoh peribahasa A yak bekenea, kabo tukuk (sebelum bertindak, pegang tengkuk), memberikan nasihat kepada kita agar berpikir sebelum berbicara, agar apa yang kita sampaikan benar adanya sehingga dapat dipertanggungjawabkan.

2. Peribahasa sebagai pemberi pengajaran. Pemberi pengajaran memiliki keterkaitan dengan pedoman dalam pendidikan. Bahwa pengajaran adalah bagian dari pendidikan. Pendidikan menurut Dewantara (2009:3) adalah "tuntunan dalam hidup tumbuhnya anak-anak." Yang dimaksudkan bahwa pendidikan menjadi jalan untuk anak-anak mencapai kehidupan sebagaimana manusia seutuhnya. Peribahasa mengingatkan individu tentang berbagai kemungkinan yang akan datang, membuat pilihan untuk bertindak, melakukan sesuatu yang akan membentuk watak dari seseorang itu sendiri. Se perti contoh peribahasa A yak miling tenlen biyoa inoa (sebelum berbicara telan liur dulu), maka dengan berpikir makna dari peribahasa ini, orang akan berpikir ulang untuk mengucapkan sesuatu atau pun melakukan tindakan sesuatu. Tidak juga diperbolehkan untuk main hakim sendiri karena terdapat peribahasa bahwa Semitak buk neak gelpung, gelpung coa tupeak buk coa putus (Menarik rambut di tepung, tepung tidak tumpah rambut tidak putus), maka masalah harus diselesaikan dengan musyawarah, bukan kekerasan. Permasalahan itu harus diselesaikan dengan penuh tanggung jawab, sesuai dengan peribahasa "tangen menetok baeu mbusung".

3. Peribahasa memberikan gambaran hidup manusia secara sosial. Kehidupan manusia secara sosial dipengaruhi oleh adat.
Penjelasan Dewantara (2009:57), “A dat merupakan sifat kepatuhan, keselarasan atau keharmonisan, yang terdapat pada keterkaitan antara tingkah laku, keadaan atau benda yang satu dengan yang lainnya". Keharmonisan itu pun berlaku antara rakyat dan pemimpinnya. Seperti contoh bagaimana kehidupan masyarakat Rejang “Rajo megang peteine, anak kutei megong kuceine (raja pegang petinya, masyarakat pegang kuncinya)", bahwa pemimpin dan rakyat harus hidup berdamping, raja tanpa rakyat tidak akan menghasilkan kehidupan yang makmur, begitu juga rakyat tanpa pemimpin akan kacau balau.

4. Peribahasa memberikan gambaran tentang norma sosial. Norma sosial berarti aturan yang berkaitan dengan aturan dalam kehidupan masyarakat. Norma sosial yang berkembang di masyarakat Rejang tercermin dalam peribahasa. Contoh peribahasa yang tampak jelas menunjukkan norma sosial adalah "ade lot ade ei" yang menjelaskan tentang sal ing menghormati saat menggunakan sarana dan prasarana yang merupakan hak milik bersama.

Begitu juga dalam kehidupan, setiap individu masyarakat juga memahami mana yang menjadi haknya dan hak orang lain. Seperti dalam peribahasa "cong laboak may biyoa" yang berarti mencincang air. Mencincang air adalah pekerjaan yang siasia, karena memotong bagaimana pun tidak akan putus. Begitu juga dalam kehidupan, mencoba menyelesaikan masalah kehidupan orang lain, yang sebenarnya bukan menjadi urusannya akan memperumit keadaan, membiarkan masalah pun akan semakin berlarut-larut seperti air yang mengalir. Sehingga harus dicari dan diselesaikan dengan baik yang masalah yang ada seperti ungkapan bebanea inde benuo dan be tutun inde jalei, dicari akar 
permasalahan, kemudian diselesaikan dengan kekeluargaan. Masalah tersebut jika sudah diselesaikan maka disudahkan seperti ungkapan "pendak dik sudo, panjang gik igei".

5. Peribahasa memberi teguran-bertujuan menegur atau melarang membuat sesuatu. Contohnya peribahasa jibeak mbin sifet lalang bidin dalen (jangan ambil sifat ilalang di jalan), memberi teguran untuk masyarakat Rejang agar mempunyai pendirian. Orang yang memiliki keteguhan hati,tidak akan mudah dipermainkan oleh orang lain.

Teguran tersebut juga berlaku dalam menyelesaikan masalah. Bahwa yang bersalah akan tetap diberikan sanksi dengan menganut sistem keadilan sesuai dengan peribahasa "mbeak temgak saman ceak". Orang yang salah tetap salah dan dihukum, orang benar harus dilindungi sesuai dengan ketentuan hukum yang berlaku.

\section{c. Pembahasan}

Ada 29 peribahasa yang dimunculkan di dalam “Kelpeak Ukum A dat Ngen Riyan Ca'o Kutei Jang" Kabupaten Rejang Lebong. Peribahasa tersebut dimunculkan untuk menyampaikan aturan-aturan adat dengan memerhatikan cara penuturan, dan melihat konteks di sekitar. Dari hasil tersebut juga tampak bahwa masyarakat Rejang berhati-hati dalam pemberian nasihat atau teguran untuk orangorang di sekitarnya. Itu menunjukkan kebudayaan dari masyarakat itu sendiri. Pada dasarnya peribahasa-peribahasa tersebut memiliki fungsi untuk mewujudkan manusia yang berbudaya.

Berbudaya berarti berbudi. Budi manusia dipengaruhi oleh dirinya, kodrat alam, dan hidup bersama (Dewantara, 2009:49). Berbudaya diwujudkan dalam tiga gejala budaya, satu di antaranya adalah "Wujud kebudayaan sebagai suatu kompleks aktivitas dari ide-ide, gagasan, nilai-nilai, norma-norma, peraturan, dan sebagainya" (Simanjutak, 2014:7). Normanorma dan peraturan tersebut diwujudkan dalam bentuk peribahasa.

Kebudayaan adalah sebuah sistem pengetahuan masyarakat, dan diwariskan melalui proses belajar. Pendidikan dalam arti kebudayaan ialah proses enkulturasi, atau proses pewarisan pengetahuan, dari satu generasi ke generasi selanjutnya (Simanjutak, 2014:87).

Dari peribasa-peribahasa yang termaktub dalam Kelpeak Ukum Adat Rejang, dapat dipelajari budaya dari masyarakat Rejang. Menjalani kehidupan secara sosial ditonjolkan, bagaimana tenggang rasa, tanggung jawab, dan kekeluargaan serta norma kesopanan. Bahkan hal yang dianggap biasa saja ternyata memberikan nilai kesopanan yang berarti. Seperti dalam peribahasa berikut "cuwuo-cuwuo samo laleu, denong-denong samo belek", yang artinya mampir sama pergi, memandang sama balik. Dalam peribahasa tersebut, ditunjukkan norma kesopanan, bahwa ketika seorang wanita dan laki-laki yang sudah disatukan dalam pernikahan wajib untuk mengunjungi rumah mertua. Bahkan jika hanya sekadar melewati rumah mertua, tetap diwajibkan mengunjugi walaupun hanya sebentar. Ini berarti kita diwajibkan untuk mempererat tali silahturahmi yang mempunyai pertalian darah maupun tidak, karena dianggap bahwa masyarakat Rejang memiliki sistem budaya kekeluargaan.

Kebudayaan yang berasal dari peribahasa Rejang perlu dicermati dan dipelajari sebagai bagian dari pengajaran dan pendidikan. Pengajaran berarti sistem untuk penyampaian ilmu yang merupakan bagian dari proses memanusiakan manusia. Pengajaran dan pendidikan dimaksudkan untuk meninggikan derajat manusia dari segi moral, ilmu, dan keterampilan. Pengajaran dan pendidikan tersebut dapat dimulai di keluarga dan di sekolah. Pendidikan di sekolah dapat dimanfaatkan untuk mentransfer nilai yang terdapat dalam peri- 
bahasa tersebut dan mengoptimalkan fungsi dari peribahasa tersebut.

Maka akhirnya, kebudayaan yang dimunculkan dalam peribahasa Rejang hendaknya diberdayakan dan diwujudkan dalam kurikulum dan pembelajaran. Nilai-nilai tersebut digali, dipelajari, dilestarikan untuk membentuk manusia-manusia Indonesia yang berkarakter. Sehingga mampu menangkis budayabudaya negatif dari luar yang akan merancuni generasi penerus.

\section{PEN UTUP}

\section{Simpulan}

Peribahasa sebagai alat pewaris nilai-nilai budaya lokal masyarakat Rejang yang luhur dan turun temurun. Peribahasa yang ditemukan di dalam Kumpulan Hukum Adat Rejang berfungsi memberikan nasihat, teguran, sindiran, pengajaran, menyampaikan mana yang baik dan yang tidak baik. Peribahasa ini harus dipertahankan dan diterapkan untuk menjaga keharmoniasan dan kerukunan masyarakat.

\section{Saran}

Peribahasa-peribahasa ini harus dipelajari dan dilestarikan oleh masyarakat Rejang itu sendiri sehingga tidak akan hilang dari ke hidupan generas-generasi mendatang. Generasi muda, khususnya, yang sekarang ini sudah banyak mengadopsi slogan dan nilai-nilai baru, perlu melestarikan keunikan nilai-nilai lokal. Nilai-nilai lokal ini tidak bisa dilupakan begitu saja, mengingat perannya yang besar sebagai pilar-pilar kehidupan daerah maupun bangsa.

\section{DAFTAR PUSTAKA}

Astika, I Made dan Yasa, I Nyoman. 2014. Sastra Lisan Teori dan Penerapannya. Yogyakarta: Graha IImu.

Badan Musyawarah Adat. 2007. Kelpeak U kum A dat $\mathrm{N}$ gen Riyan $\mathrm{Ca}$ 'o Kutei Jang Kabupaten Rejang Lebong. Rejang Lebong: Badan
Musyawarah Adat Kabupaten Rejang Lebong.

Baried, Siti Baroroh, dkk. 1985. Pengantar Teori Filologi. Yogyakarta: Badan Penelitian dan Publikasi Seksi Filologi Fakultas Sastra UGM.

Creswell, John W. 2009. Research D esign Qualitative, Quantitative, and M ixed $M$ ethods A pproaches. Diterjemahkan ke dalam Research Design Pendekatan Kualitatif, Kuantitatif, dan M ixed oleh SaifuddinZuhri Qudsy. 2014. Yogyakarta: Pustaka Pelajar.

Dewantara, Ki Hadjar. 2009. M enuju M anusia M erdeka. Yogyakarta: Pustaka Puitika.

Hassan, Hasmidar dan Jaafar, Jafizah. 2016.

Penginterpretasian Peribahasa dan Hubungannya dengan Kemahiran Berfikir: Analisis Berdasarkan Teori Relevans. M yjurnal, Volume 29 No. 1: 94-119. http:/ / www.myjurnal.my/ public/ articleview.php?id=96542. Diunduh 09 November 2017.

Herlambang, dkk. 2004. "Inventarisasi Institusi A dat Rejang dalam Rangka Penyusunan Kompilasi Hukum A dat Rejang". Jurnal M edia Hukum 2004 Fakultas Hukum U M Y Hal. 1-15. http:/ / repository.unib.ac.id/ 7451/ 1/ Lamp.\%202.\%20juni2013Inventa riasi $\% 20$ I nstitusi \%20A dat\%20Rejang\% 20finaLI.pdf. Diunduh 17 Juli 2017.

Hutomo, Suripan Sadi. 1991. M utiara yang

Terlupakan Pengantar Studi Sastra Lisan.

Surabaya: HISKI-Komisariat Jawa Timur. Lebong. 2007. Serambeak: Sastra Lisan Suku Rejang yang $N$ yaris Punah. http:/ / rejanglebong.blogspot.co.id/2008/ 02/ serambeak-sastra-lisan-suku-rejangyang.html. Diunduh 08 November 2017.

Moleong, Lexy J. 2007. M etodologi Penelitian Kualitatif. Bandung: PT Remaja Rosdakarya.

Pujiastuti, Indah. 2017. M embangun Karakter M elalui A dat Istiadat "Kelpeak U kum A dat 
$\mathrm{N}$ gen Riyan Ca'o Kutei Jang" Kabupaten Rejang Lebong. Makalah disajikan dalam Conference on Language Teaching, FKIP Untidar, 26 Oktober.

Pulungan, Anni Holila. 2013. Kajian Etnolinguistik Terhadap Peribahasa dalam Bahasa Indonesia: Sebuah Tijauan Pragmatic Force (D aya Pragmatik. http:// digilib.unimed.ac.id/4 $19 / 1 /$ Anni\%20H olila\%20Pulungan.pdf. Diunduh 10 November 2017.

Simanjutak, Bungaran A ntonius (ed.). 2014. Korelasi Kebudayaan dan Pendidikan:M embangun Pendidikan Berbasis Lokal. Jakarta: Yayasan Pustaka Obor Indonesia.

Sugono, Dendy (ed.). 2011. Buku Praktis Bahasa Indonesia 2. Jakarta: Kementerian Pendidikan dan Kebudayaan.
Sunarni, Nani. 2017. Efektifitas "Pewarisan Peribahasa" M elalui Pendidikan M asyarakat sebagai M edia Pembentuk Karakter Bangsa Indonesia di Era Global. Artikel disajikan dalam Seminar Nasional \#3 Bahasa dan Sastra Indonesia dalam Konteks Global, Universitas Jember, 22 Maret.

Widyastuti, Susana. 2010. Peribahasa: Cerminan Kepribadian Budaya Lokal dan Penerapannya di M asa Kini. http:/ / staffnew.uny.ac.id/ upload/132316016/ penelitian/ P e r i bah a $\mathrm{s}+\mathrm{C}$ ermi na $\mathrm{n}+$ Kepribadian+Budaya+Lokal.pdf. Diunduh 10 November 2017.

Yulyasa, Resti dkk. 2017. Leksikon N ama Tumbuhan dalam Peribahasa M asyarakat M elayu Sekadau. Jurnal Pendidikan dan Pembelajaran Untan Vol. 6 No. 82017. http:/ / jurnal.untan.ac.id/ index.php/ jpdpb/ article/ viewFile/ 21442/ 17382. Diunduh 10 November 2017. 